\title{
The Formation Mechanism and Model Construction of Border County Tourism Competitiveness in China
}

\section{Y.Q. SHI}

Institute of Geographic Sciences and Natural Resources Research, CAS, Beijing 100101, China; University of Chinese Academy of Sciences, Beijing 100049, China

\section{L.S.Zhong \& T.Chen}

Institute of Geographic Sciences and Natural Resources Research, CAS, Beijing 100101, China

\begin{abstract}
With the booming development of border tourism in China, competitions among different tourism destinations in border areas are becoming increasingly fierce. Model construction is the basic work for tourism competitiveness research in border counties. The study analyzes the characteristics of border county tourism competitiveness, summarizes affecting factors and formation mechanism, then constructs a conceptual model consisted with exterior and interior competitiveness. Exterior competitiveness is the ultimate performance of tourism competitiveness in border counties, which is measured by tourism arrivals and revenues. Interior competitiveness can explain the causes of tourism competitiveness formation more specifically, which involves supporting and driving factors of tourism development. The study concludes that in order to provide reference for establishment of scientific strategy on tourism development in border counties, the study of characteristics of competitive factors on spatiotemporal variations and a deep analysis on driving mechanism of different types of border counties should be strengthened in the future.
\end{abstract}

KEYWORD: Border county; Tourism competitiveness; Formation mechanism; Model construction

\section{INTRODUCTION}

Border tourism can build a mutual promotion industry cluster in border areas and become a link and bridge connecting domestic and international tourism market (Chen 2004), which is a new focus for tourism geography research. Border tourism, which started in 1980, has developed rapidly and shown strong development tendency in China. The competition of border tourism has transited from scenic spots competition into city and regional competition. Statistics from economy and society developed statistical bulletin of border counties calculates that the ratio of tourism revenue to GDP in border counties rises from $9.24 \%$ in 2006 to $10.52 \%$ in 2011 . The number of border counties with tourism revenue over $30 \%$ of GDP rises from 6 in 2006 to 14 in 2011 (Shi et al. 2014). Thus it can be seen that the level of border tourism competition varies in different regions and the research of border tourism requires immediate attention.

China's land borders, stretched from Yalu River in Dandong, Liaoning Province to Beibu Gulf in Fangchenggang, Guangxi Province, are about 2.2 million $\mathrm{km} .136$ border counties and 14 neighboring countries are distributed online(Zhang 1997). This paper analyzes the characteristics of border county tourism competitiveness, summarizes affecting factors and formation mechanism of tourism competitiveness in border counties, then constructs a model consisted with exterior and interior competitiveness in order to deepen theoretical research of border tourism and to provide a new perspective for tourism competitiveness study.

\section{CHARACTERISTICS OF TOURISM COMPETITIVENESS IN BORDER COUNTIES}

\subsection{Comprehensiveness and openness}

Tourism competitiveness in border counties is influenced by border resources, strategy and structure of its organization, support and guidance of government, promotion by correlated industry, tourist demands and border effects. Moreover, the formation and evolution of tourism competitiveness in border counties not just affected by county's internal environment, but by external environment including neighboring country. Tourism system in border counties has highly interaction with other tourism destinations on aspects of people, cash, information and goods flow, which reflects tourism competitive power. 


\subsection{Diversity}

From the perspective of dominant factors in tourism competition, 4 types of tourism competitiveness can be identified. (1) Border trade-driving model. The gradual development of tourism in most border counties was followed with the progress of border trade. (2) Tourism resource-driving model. There are rich and unique tourism resources in these counties, which constitutes comparison advantage in border areas. (3) Demand-driving model. Huge tourism market will become the headspring of tourism development as the improvement of people's living conditions and yearn for tourism in border areas. (4) Government-leading model. Counties of this kind often own good economic foundation, convenient transportation conditions and good relationship with neighboring countries. Governments offer solid financial support for tourism development, which ensures the construction of infrastructure and scenic spots.

\subsection{Significantly influenced by border effect}

Border effect is the effect on cross-border behavior, which is closely related to politic, economy, culture, society in border areas (Zhu \& Gu 2008). On one hand, tourism in border areas is developed in highly sensitive environment, in which terrorism, illegal immigrant inhibits tourism development in border counties. On the other hand, cooperation between two neighboring countries accelerates the flow of tourists. Price variance of products and services, language, custom and art difference between two neighboring countries, transit formalities, border policy and international environment can be influence the power of tourism competitiveness in border areas.

\subsection{Dynamic}

The formation of tourism competitiveness in border counties is a dynamic process. The tourism competitiveness power is different with the different combinations of affecting factors in different developing phases. Generally speaking, in initial period of tourism development, the access to tourism competitiveness in border areas depends on the advantage of resources and border trade, which have high requirement of tourism resources and vitality of crossing border. At the medium-term of tourism development, the access to tourism competitiveness in border areas is to further strengthen product development and differentiates tourism products, which have high requirement of capital. At the lateterm of tourism development, the access to tourism competitiveness in border areas depends on continuous optimization and update of tourism products, which have high requirement of science and technology, talents and innovation. Therefore, tourism competitiveness can be enhanced by improving the different combinations of affecting factors.

\section{FORMATION MECHANISM OF TOURISM COMPETITIVENESS IN BORDER COUNTIES}

The formation and development of tourism competitiveness is the process of access, innovation and integration of tourism competence factors (Cao $\& \mathrm{Li}$ 2010). Following the law of comparative advantage, the embeddedness of local border resources is the source of tourism formation and development, which includes natural resources, human resources, position resources, capital resources, manpower resources, knowledge resources, etc. Resources in border counties are inherent advantage for tourism development, which is monopoly and exclusive. The more unique the tourism resources, the stronger competitiveness the border counties have. However, only under the mature conditions can comparative advantage turn into the economic advantage. Its external driving force includes demands of tourism market, guidance and support of the government, border trade, promotion of relevant industries, etc. Additionally, border ports as a significant component of tourism resources distinguishes border tourism from general tourism. In these border counties, border trade, foreign culture experience, characteristic architectures, border service center and tourism exclave are special tourism attractions.

According to the theory of competitive advantage, tourism industry structure changing, innovation of technological institution and industry cluster guarantee the effective resource utilization and transformation from monopolistic tourism resources to tourism product which can participate in market competition. With the further improvement of tourism components in border counties, a fully functional supply system is formed, and competitive advantage is gradually developed. At this stage, differential tourism resource exploitation is needed, and tourism products updating should be kept. Tourism competitiveness in border counties gradually transfers from resource competition to capital, technology and talent competition. The ability to open up tourism market and make profits is the ultimate performance of tourism competitiveness, which is measured by tourist arrivals and tourism revenue.

\section{MODEL CONSTRUCTION}

\subsection{Affecting Factors of Tourism Compeititveness in Border Counties}

The development of tourism competitiveness in 
border counties is the result of many factors (Prideaux 2005). Resources, internal supporting factors and external driving factors are three aspects which are identified in this paper. Resources are the natural substances for tourism development in border areas. Internal supporting factors and external driving factors are the inner and external strength of tourism development respectively. These three aspects are related closely which makes combined contribution to tourism competitiveness in border areas.

\subsubsection{Resources}

(1) Natural environment. Natural environment including climates, geomorphologic landscape, plants cover constitutes important part of tourism competitiveness, which is directly experienced by tourists. The various topograhic types and complicated climate provide basic conditions for formation and competition of tourism development in border areas. (2) Tourism resources. The quantity and quality of tourism resources in border areas affects the tourism market size, hierarchy of tourists demands. The more unique the tourism resources, the stronger competitiveness the border counties have. Besides natural tourism resources, human tourism resources, border port resources are included which have a strong appeal to tourists. (3) Location and transportation. This factor can largely determine the position, function, time sequence and level of tourism development (Dong et al. 2009). Superior location and transportation can reduce the time cost to tourism destination, enhance the material, energy and information exchange capacity, thus improving tourism competitiveness.

\subsubsection{Internal supporting factors}

(1) Tourism organization structure. Tourism organization structure is the micro-foundation of tourism competitiveness development which includes entertainment industry, accommodation and catering industry, travel services, tourism transportation, tourism production and sales company. The influences of this factor can be explained from two aspects. Firstly, tourism competitiveness is derived from creation of competitive environment. The organization structure of inner-enterprise is the key factor to enhance tourism competitiveness. Secondly, economies of scale can reduce costs, which affect competitive advantage of tourism organization structure. (2) Social economic development level. This factor not only ensures the construction of tourism service facilities, but also stimulates both real and potential tourist market demand. (3) Technological and institutional innovation. Technological innovation mainly includes innovation of advertisement and Internet marketing methods, intelligent management system in tourist attractions and hotels. Institutional innovation mainly includes innovation of enterprise organization mode, property right structure, market rule and relative policies. (4) Tourism human resources. The quantity, cultural quality, ideology and science literacy of tourism talents plays a crucial role in tourism competitiveness enhancement. (5) Tourism culture. Tourism culture is the outward manifestation of human inner values, which is the marrow and soul of tourism and the key to enhance tourism competition.

\subsubsection{External driving factors}

(1) Tourism market demands. Tourists' demand for tourism products and services is a motive force of tourism development in border areas. It can stimulate tourism industrial innovation and improvement of tourism services in order to meet tourists' preference. (2) Government support. Government is playing the role of macro-control of tourism development in border areas, which is an indispensable force of competitiveness enhancement. Tourism policies and management systems set by government provide strategic guidance on tourism development. (3) Border trade. Trade boosts economic ties between two neighboring countries and economic ties pushes personnel exchange, which is the direct impetus for tourism development (Sun et al. 2011). (4) Tourism industrial cluster. Firstly, aggregation of plenty of tourism enterprises in a large region not only can achieve economic of scale effects, but is beneficial to the formation of differentiated competitive advantage. Secondly, the expansion of tourism industry provides new sources of profits. (5) Geo-politics and economy pattern. Tourism in border counties is developed in highly sensitive environment. The complexity of social and economic system and huge disparities of economic development level between neighboring countries, to a certain degree, determines the tourism competitiveness power in border counties.

\subsection{Conceptual model}

In accordance with the scientific and comparable operational principles, this paper constructs appraisal index system of tourism competitiveness in border counties, which involves interior competitivenss and exterior competitivenss. Exterior tourism competitiveness is the ultimate performance of border tourism competitiveness, which is measured by tourism market, including tourist arrivals and tourism revenue. Interior competiveness is the determinants of exterior competitiveness, which can better explain tourism competitiveness (Fig.1).

\subsection{Evaluation model}

Weighted average method is used to calculate 
tourism competitiveness in border counties, the formula are as follows:

$$
F_{i}=\sum_{j=1}^{m} \omega_{j} \times \Phi\left(e_{i j}\right)
$$

Where $F_{i}$ is tourism competitiveness evaluation index of border county $i, \omega_{j}$ is entropic weight coefficient of $j, \Phi\left(e_{i j}\right)$ is membership function value of index $j$ in border county $i, m$ is the number of indexes.

\section{CONCLUSIONS}

In conclusion, the study analyzes the characteristics of border county tourism competitiveness, summarizes formation mechanism of tourism competitiveness in border counties, then constructs a model consisted with exterior and interior competitiveness. Exterior competitiveness is the ultimate performance of tourism competitiveness in border counties, which is measured by tourism arrivals and revenues. Interior competitiveness can explain the causes of tourism competitiveness formation more specifically, which involves supporting and driving factors of tourism development. This paper consummates the study system on border tourism competitiveness and concludes that the study of characteristics of competitive factors on spatiotemporal variations and a deep analysis on driving mechanism of different types of border counties should be strengthened in the future.

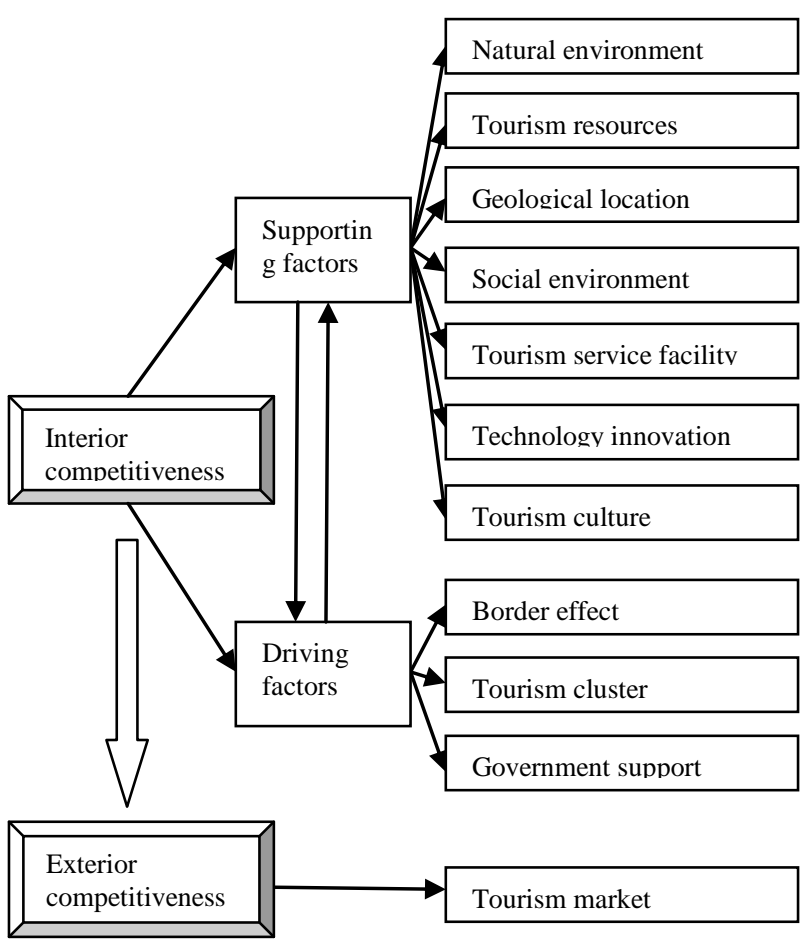

Figure 1. General framework of tourism compeititveness model in border counties

\section{ACKNOWLEDGEMENT}

This study was sponsored by Science and Technology Plan Projects of IGSNRR (2012BG005) and the National Natural Science Foundation of China (41171435).

\section{REFERENCES}

[1] Cao, Y.Y. \& Li, F.X. 2010. Research on mechanism of formation and development of regional tourism industry competitiveness based on self-organizing system theory. Soft Science 24(2): 83-88.

[2] Chen, G.Q. 2004. Study on the tactic meaning of the development frontier tourism in China. East China Economic Management 18(2): 36-38.

[3] Dong, S.C. et al. 2009. A discussion about appraisal index system of tourism competitiveness and measuring method in urban agglomeration. Tourism Tribune 24(2): 30-36.

[4] Prideaux, B. 2005. Factors affecting bilateral tourism flows. Annals of Tourism Research 32(3): 780-801.

[5] Shi, Y.Q. et al. 2014. Evaluation of border tourism competitiveness at the county level in China. Resources Science 36(6): 1133-1141.

[6] Sun, G.N. et al. 2011. Scenery attraction, location accessibility and trade connection: three factors and their influences on destination choice of Japanese tourists. Geographical Research 30(6): 1032-1043.

[7] Zhang, G.R. 1997. Strategic options of border tourism development in China. Beijing: Economic and Management Press.

[8] Zhu, H.X. \& Gu, H.Y. 2008. The border effect of sino-US agricultural trade based on gravity model. Finance and Trade Research 23(3): 58-65. 